\title{
Effects of fish and nutrient additions on food-web stability in a charophyte-dominated lake
}

\author{
WOUTER J. VAN DE BUND AND ELLEN VAN DONK \\ Centre for Limnology, Netherlands Institute of Ecology, Nieuwersluis, The Netherlands
}

\section{SUMMARY}

1. The response of major food-web constituents to combinations of nutrient addition and zooplanktivorous fish abundance was tested during two subsequent years in the shallow charophyte-dominated lake Naardermeer in the Netherlands, using in situ enclosures. 2. Treatment effects differed sharply between study years. In 1998, when the summer temperature was low $\left(17-21^{\circ} \mathrm{C}\right)$, high algal biomass only developed at high nutrient levels in the presence of fish, but with no major effect on Chara biomass. In 1999, when the summer temperature was relatively high $\left(20-25^{\circ} \mathrm{C}\right)$, algal blooms occurred at high nutrient levels regardless of fish abundance, and were associated with a drastic decline in Chara biomass.

3. Differences between years in temperature and initial zooplankton composition and biomass were likely to contribute to the varying relative importance of top-down and bottom-up effects in these enclosure experiments.

4. The results suggest that when nutrient loads are increased towards levels where the macrophyte-dominated state is being destabilised, a 'switch' is more likely to occur in warm summers.

Keywords: enclosures, multiple stable states, shallow lakes, submerged macrophytes, turbidity

\section{Introduction}

In shallow lakes, positive feedback mechanisms have been identified that tend to stabilise either a clear, macrophyte-dominated state, or a turbid state dominated by algal blooms within a certain range of nutrient conditions (Scheffer et al., 1993). The relative importance of top-down and bottom-up control can vary widely both between lakes and between years (Jeppesen et al., 1999). Submerged macrophytes play a very important role in stabilising the clear-water state in shallow mesotrophic and eutrophic lakes (Perrow et al., 1997; Scheffer, 1998). Because charophytes are able to colonise lakes rapidly (Simons et al., 1994; Beltman \& Allegrini, 1997; Meijer et al., 1999), they often play an important role in early stages of

Correspondence: Wouter J. Van de Bund,

EC Joint Research Centre, Institute for Environment and

Sustainability, TP 290, I-21020 Ispra (VA), Italy.

E-mail: wouter.van-de-bund@jrc.it

(c) 2004 Blackwell Publishing Ltd recovery after reduction of high anthropogenic nutrient inputs (Simons et al., 1994; Van den Berg, 1999). There is much evidence that charophytes have a particularly strong positive effect on water transparency (Crawford, 1979; Scheffer et al., 1994; Van den Berg et al., 1998; Van Donk \& Van de Bund, 2003.

Responses of macrophytes, phytoplankton, zooplankton and other important food-web constituents to combinations of nutrient addition and the abundance of zooplanktivorous fish were tested in in situ enclosures in a shallow lake dominated by charophytes. Experiments were part of a series of simultaneous experiments at six locations throughout Europe with the general aim to investigate the response of food webs in shallow macrophyte-dominated lakes to nutrient enrichment and fish predation in different climatic conditions (the International Mesocosm Experiement; Stephen et al., 2004a). Our expectation was that because of the presence of charophytes it would be particularly difficult to induce a 'switch' to a turbid state. 


\section{Methods}

\section{Study area}

Experiments were carried out in the main basin of Naardermeer ('Grote Meer North'). Naardermeer (latitude $52^{\circ} 2^{\prime} \mathrm{N}$, longitude $5^{\circ} 1^{\prime} \mathrm{E}$ ) is a shallow lake with a surface area of $10.42 \mathrm{~km}^{2}$ and a mean depth of $1 \mathrm{~m}$. The lake is located approximately $20 \mathrm{~km}$ east of Amsterdam in the Netherlands. A detailed description of local geological, hydrological and biological characteristics, as well as the history of Naardermeer is given in Bootsma, Barendregt \& Van Alphen (1999). The lake's main basin is almost completely covered by submerged macrophytes (Chara aspera Detharding and Myriophyllum sp.). During the 1960s, eutrophication led to loss of the submerged macrophyte vegetation dominated by charophytes and to subsequent cyanobacterial blooms in the lake. Extensive restoration measures were initiated in 1985, including a drastic reduction of external nutrient loading by hydrological isolation of the area and chemical phosphate removal from the suppletion water necessary to maintain lake water levels during the summer months. These measures have resulted in a decrease of total phosphorus concentrations in the lake from $0.1 \mathrm{mg} \mathrm{P} \mathrm{L} \mathrm{P}^{-1}$ in 1985 to $<0.03 \mathrm{mg} \mathrm{P} \mathrm{L}^{-1}$ in 2000 (summer averages). Total nitrogen concentrations also decreased, although less strongly - from $1.5 \mathrm{mg} \mathrm{L}^{-1}$ in 1985 to $1.0 \mathrm{mg} \mathrm{L}^{-1}$ in 2000 (summer averages). The turbidity drastically decreased, and the submerged vegetation recovered. Recolonisation by vegetation was not immediate, but became evident after a delay of approximately 5 years from the start of the restoration measures.

\section{Enclosure experiments}

In 1998 and 1999, two mesocosm experiments were carried out as part of a series of simultaneous experiments at six locations throughout Europe to investigate the response of food webs in shallow macrophyte-dominated lakes to nutrient enrichment and fish predation (Stephen et al., 2004a). The enclosures consisted of polyethylene cylinders with a diameter of $1 \mathrm{~m}$. They were open to the substratum, thus included sediment and vegetation, and enclosed 500-800 L of lake water. The sites of the 1998 and 1999 experiments were within the same general area of the lake. At both locations the water depth was ca. $1 \mathrm{~m}$, with dense and homogeneous beds of C. aspera. Both experiments comprised 36 enclosures, with different fish and nutrient treatments. Details of the treatments were slightly different between years (Table 1). In 1998, there were twelve treatments: three zooplanktivorous fish levels (from 0 to $20 \mathrm{~g}$ fresh mass $\mathrm{m}^{-2}$ ), and four nutrient levels (weekly addition of $0-10 \mathrm{mg}$ $\mathrm{N} \mathrm{L}^{-1}$ as $\mathrm{NaNO}_{3}$ and $0-1 \mathrm{mg} \mathrm{P} \mathrm{L}{ }^{-1}$ as $\mathrm{KH}_{2} \mathrm{PO}_{4}$ ), with three replicates for each treatment. In 1999 there were 18 treatments with two replicates each. The fish treatments were the same as in 1998, but there were six nutrient levels (weekly addition of $0-3 \mathrm{mg} \mathrm{N} \mathrm{L}^{-1}$ and $0-0.3 \mathrm{mg} \mathrm{P} \mathrm{L}^{-1}$ ).

The fish species used in both experiments was rudd (Scardinius erythrophthalmus), with average fork lengths of 4.5 and $5.5 \mathrm{~cm}$ in 1998 and 1999, respectively. The 1998 experiment lasted 5 weeks (8 June to 13 July), the 1999 experiment 6 weeks (28 June to 9 August). Enclosures were deployed 3 days before adding the fish and applying the first nutrient addition; before fish addition, enclosures were electrofished to remove any fish that may have been enclosed when the mesocosms were set up. In the course of the experiment the presence of fish was checked weekly using a bathyscope, and fish were replaced in the rare cases where mortality occurred.

In the 1998 experiment, a storm and the resulting strong wave action caused the loss of 8 of the 36 enclosures during the second week of the experiment.

Table 1 Treatment levels of the 1998 and 1999 enclosure experiments in Naardermeer, the Netherlands

\begin{tabular}{|c|c|c|c|c|c|}
\hline \multirow[b]{2}{*}{ Year } & \multirow{2}{*}{$\begin{array}{l}\text { Fish } \\
\text { treatment } \\
\text { level }\end{array}$} & \multirow{2}{*}{$\begin{array}{l}\text { Fish } \\
\text { density } \\
(\mathrm{g} \text { fresh } \\
\text { mass } \mathrm{m}^{-2} \text { ) }\end{array}$} & \multirow{2}{*}{$\begin{array}{l}\text { Nutrient } \\
\text { treatment } \\
\text { level }\end{array}$} & \multicolumn{2}{|c|}{$\begin{array}{l}\text { Weekly nutrient } \\
\text { addition }\end{array}$} \\
\hline & & & & $\begin{array}{l}\text { Nitrogen } \\
\left(\mathrm{mg} \mathrm{L}^{-1}\right)\end{array}$ & $\begin{array}{l}\text { Phosphorus } \\
\left(\mu \mathrm{g} \mathrm{L}^{-1}\right)\end{array}$ \\
\hline \multirow[t]{4}{*}{1998} & 0 & 0 & 0 & 0 & 0 \\
\hline & 1 & 4 & 1 & 1 & 100 \\
\hline & 2 & 20 & 2 & 5 & 500 \\
\hline & & & 3 & 10 & 1000 \\
\hline \multirow[t]{6}{*}{1999} & 0 & 0 & 0 & 0 & 0 \\
\hline & 1 & 4 & 1 & 0.3 & 30 \\
\hline & 2 & 20 & 2 & 0.6 & 60 \\
\hline & & & 3 & 0.9 & 90 \\
\hline & & & 4 & 1.5 & 150 \\
\hline & & & 5 & 3.0 & 300 \\
\hline
\end{tabular}

Rudd (Scardinius erythrophthalmus L.) was used in the fish treatments in both years. 
Because the lost enclosures were quite evenly distributed across the experimental treatments, it was still possible to perform meaningful statistical analyses. In 1999, the weather was very calm and warm during the entire experiment; none of the enclosures was lost.

\section{Sampling and measurements}

Detailed descriptions of the sampling and analytical methods are given in Stephen et al. (2004b). All enclosures were sampled weekly for water chemistry, zooplankton, and phytoplankton. Water temperature was measured using a thermistor probe in the surface water in mid-morning from a random sample of ten enclosures. Secchi disc transparency was measured if the bottom was not visible.

Integrated water samples for chemical analysis, zooplankton and phytoplankton were taken every week with a $5-\mathrm{cm}$ diameter tube extending to the depth of the water column above the Chara bed. $\mathrm{pH}$ was measured electronically on unfiltered water, as was alkalinity by titration with $0.1 \mathrm{M}$ hydrochloric acid. Total phosphorus concentrations were also determined on unfiltered water, after digestion with acid persulphate.

Water for other analyses was filtered through Whatman GF/C filters. Total soluble phosphorus was determined after persulphate digestion and soluble reactive phosphorus directly. Nitrate was determined by reduction to nitrite on spongy cadmium and subsequent diazotisation and spectrophotometric measurement of the pink dye formed. Ammonium was determined by indophenol blue formation and subsequent spectrophotometry.

Chlorophyll $a$ was extracted from filters into 90\% ethanol in a $75{ }^{\circ} \mathrm{C}$ water bath for $5 \mathrm{~min}$ and measured spectrophotometrically. Dry weight of suspended solids was also determined with weighed filters. A portion of the depth-integrated water sample was preserved with Lugol's iodine for subsequent phytoplankton counts with an inverted microscope. Zooplankton samples $(7 \mathrm{~L})$ were taken from the integrated water sample and passed through a 50$\mu \mathrm{m}$ mesh, preserved in ethanol and counted under a dissecting microscope. Counts were converted to biovolumes by measuring lengths of individual organisms and applying published length-biomass relationships. Agreed protocols were used standard- ising counting, measuring, and biovolume conversion procedures (Stephen et al., 2004b).

Fish were removed from enclosures at the end of the experiment by electrofishing. Macrophyte biomass was then determined by removing all living plant material using a rake and weighing the collected material after drying at $100{ }^{\circ} \mathrm{C}$ to constant weight. No correction was made for attached marl.

\section{Statistical methods}

For all zooplankton, phytoplankton and water chemical variables time-weighted averages were calculated for each enclosure in each experiment (Stephen et al., 2004a). Week number was used as a weighting factor; pretreatment data were not included. Data were appropriately transformed (log, square root or arcsine transformations, depending on the variable) to meet ANOVA requirements. Data were analysed separately for the 2 years by two-way analysis of variance, with fish and nutrients as treatment variables. For more detail see Stephen et al. (2004a).

\section{Results}

In 1998, the water temperature was considerably lower than in 1999 throughout the experiment (average difference of $4{ }^{\circ} \mathrm{C}$ ). Concentrations of nitrate, phosphate and ammonium, as well as $\mathrm{pH}$ levels were influenced by nutrient additions, but not by the presence of fish. These patterns were evident in both years (Table 2). Nutrient concentrations in the enclosures did not exceed levels of the weekly additions (Fig. 1), indicating that there was no net accumulation of nutrients in the water, not even at the highest level of addition. In spite of the higher levels of nutrient addition in 1998, concentrations of total and soluble reactive phosphorus (Fig. 1a,b) and nitrate (Fig. 1c), were consistently lower than in 1999. Ammonium concentrations (Fig. 1d) were also considerably lower in 1998. Furthermore, $\mathrm{pH}$ was generally lower in 1998, especially in enclosures where no nutrients were added (Fig. 2).

Chara biomass was not significantly affected by fish treatments in either year, and decreased with nutrient addition in the 1999 experiment only (Table 2). In enclosures with the two highest nutrient levels, more than $90 \%$ of the Chara biomass disappeared in that year (Fig. 2). We observed that the Chara looked less 
Table 2 Effects of fish and nutrient addition on chemical and biological parameters in enclosure experiments in Naardermeer, the Netherlands

\begin{tabular}{|c|c|c|c|c|c|c|}
\hline \multirow[b]{2}{*}{ Variable } & \multicolumn{2}{|l|}{ Fish } & \multicolumn{2}{|c|}{ Nutrient } & \multicolumn{2}{|c|}{$\begin{array}{l}\text { Fish } \times \\
\text { nutrient }\end{array}$} \\
\hline & 1998 & 1999 & 1998 & 1999 & 1998 & 1999 \\
\hline Soluble reactive phosphorus & n.s. & n.s. & $* * *$ & $* * *$ & n.s. & n.s. \\
\hline Nitrate & n.s. & n.s. & $* * *$ & $* * *$ & n.s. & n.s. \\
\hline Ammonium & n.s. & n.s. & $* * *$ & $* * *$ & n.s. & n.s. \\
\hline $\mathrm{pH}$ & n.s. & n.s. & $* * *$ & $* * *$ & n.s. & n.s. \\
\hline Chara biomass & n.s. & n.s. & n.s. & $* * *$ & n.s. & n.s. \\
\hline Planktonic chlorophyll $a$ & $* *$ & n.s. & $* * *$ & $* *$ & * & n.s. \\
\hline Total phytoplankton biomass & * & n.s. & $* * *$ & n.s. & n.s. & n.s. \\
\hline Total cyanobacteria biomass & n.s. & n.s. & $* * *$ & $* *$ & n.s. & n.s. \\
\hline Total cryptophyte biomass & $* *$ & n.s. & $* * *$ & * & n.s. & n.s. \\
\hline Total chlorophyte biomass & * & n.s. & $* * *$ & $*$ & * & n.s. \\
\hline Total zooplankton biomass & $* * *$ & n.s. & n.s. & * & n.s. & n.s. \\
\hline Small cladocerans biomasss & $* * *$ & n.s. & n.s. & * & n.s. & n.s. \\
\hline Large cladocerans biomass & $* * *$ & n.s. & n.s. & n.s. & n.s. & n.s. \\
\hline Raptorial zooplankton biomass & * & n.s. & n.s. & $* *$ & n.s. & n.s. \\
\hline
\end{tabular}

Two-way ANOVAs were run separately for the 1998 and 1999 experiments.

n.s., not significant; ${ }^{*} P<0.05 ;{ }^{* *} P<0.01 ;{ }^{* * *} P<0.001$.

healthy in high-nutrient enclosures, especially in the 1999 experiment; the plants were yellow instead of green, and there appeared to be more algal and bacterial growth on internodes and branches.

Treatment effects on chlorophyll $a$ concentration also differed between study years (Table 2; Fig. 2). In 1998 chlorophyll $a$ levels increased with both fish and nutrient additions. Furthermore, there was a significant interaction between fish and nutrients, indicating a stronger fish effect at high nutrient levels. In 1999 there was again a significant increase in chlorophyll $a$ concentration with nutrient addition, but neither the effect of fish nor the interaction between fish and nutrients was significant.

Although the response of total phytoplankton biomass (Fig. 3) to the experimental treatments was quite similar to the response of chlorophyll $a$ (Fig. 2), there were differences in the details of these related responses. Error variances were considerably higher for total phytoplankton biomass than for chlorophyll $a$, resulting in generally lower significance levels (Table 2). This occurred especially in the 1999 experiment, where none of the treatment effects was significant.

Cyanobacteria, green algae, and cryptophytes together comprised $>95 \%$ of the phytoplankton
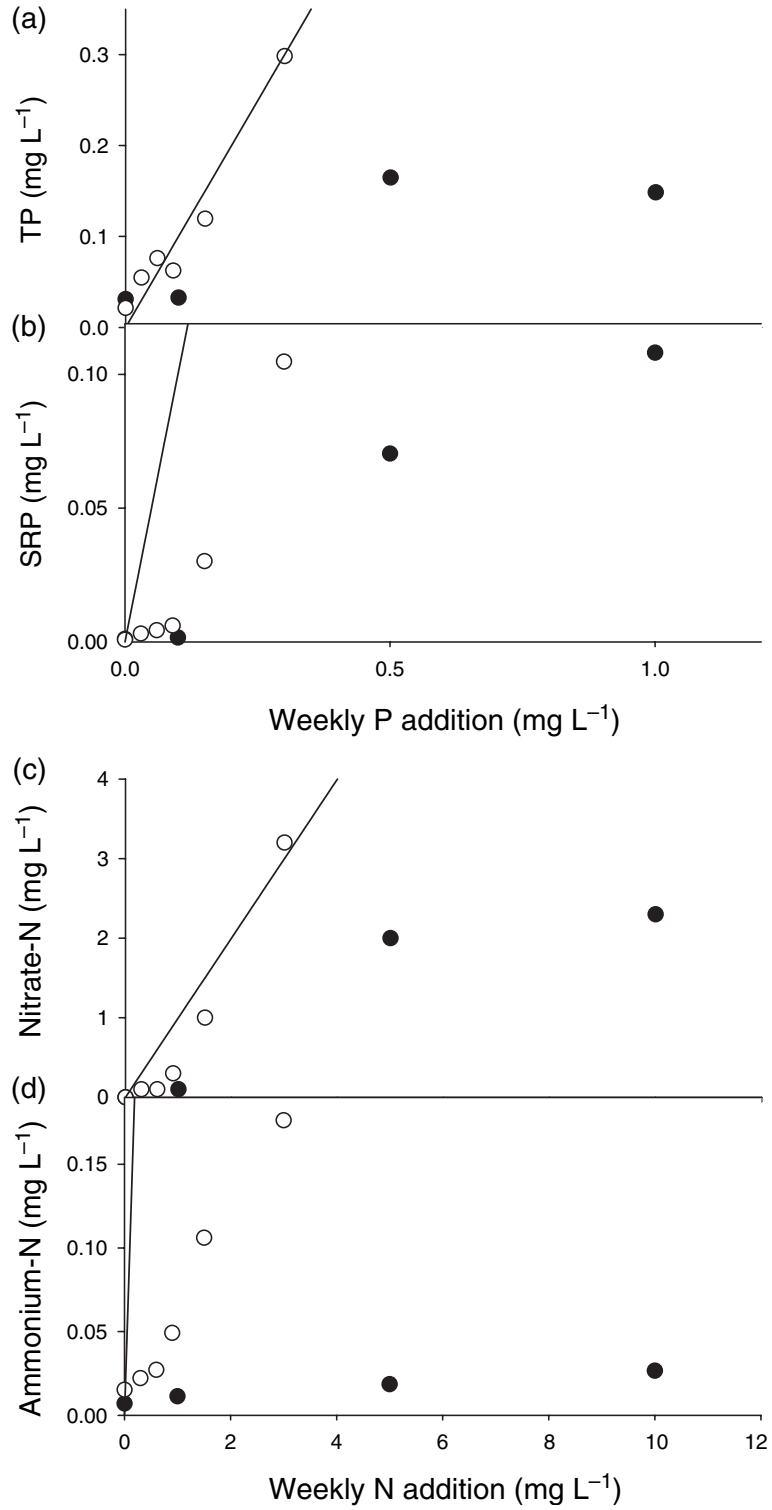

Fig. 1 Nutrient concentrations versus nutrient addition in two mesocosm experiments in Naardermeer, the Netherlands, in 1998 (closed circles) and 1999 (open circles). (a) total phosphorus (TP); (b) soluble reactive phosphorus SRP; (c) nitrate, and (d) ammonium. Solid lines indicate concentrations expected from the weekly nutrient additions.

biomass. During both years, nutrient additions influenced cyanobacterial biomass, while fish and fishnutrient interaction effects were not significant (Fig. 3; Table 2). In 1999 cyanobacterial biomass first increased then decreased with increasing nutrient concentrations. In 1998 the highest cyanobacteria biomasses were reached at intermediate levels of nutrient addition, decreasing again towards the 
1998

(a)

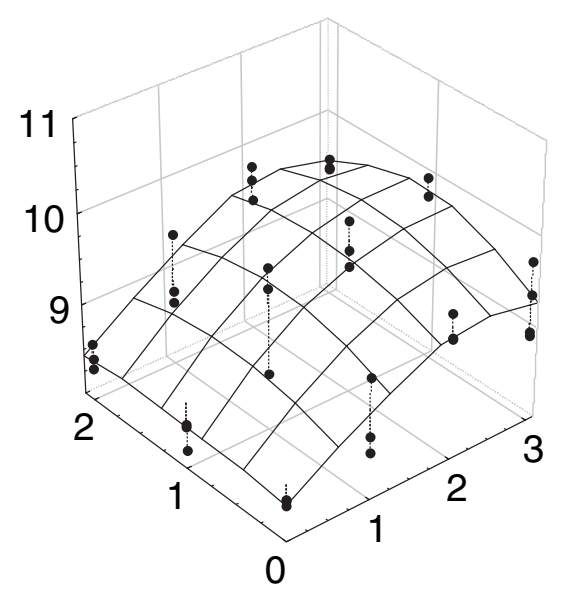

(b) 2000

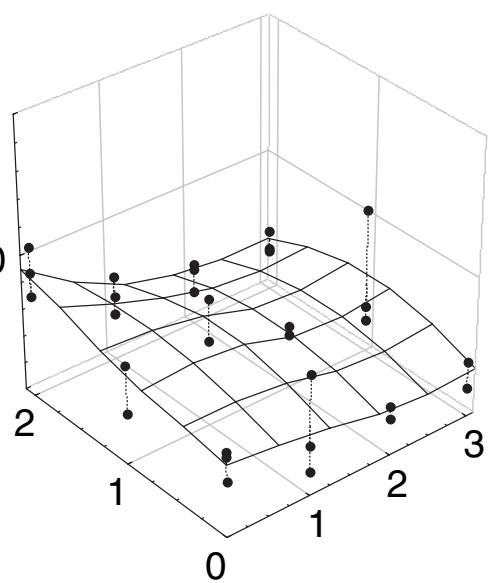

(c)

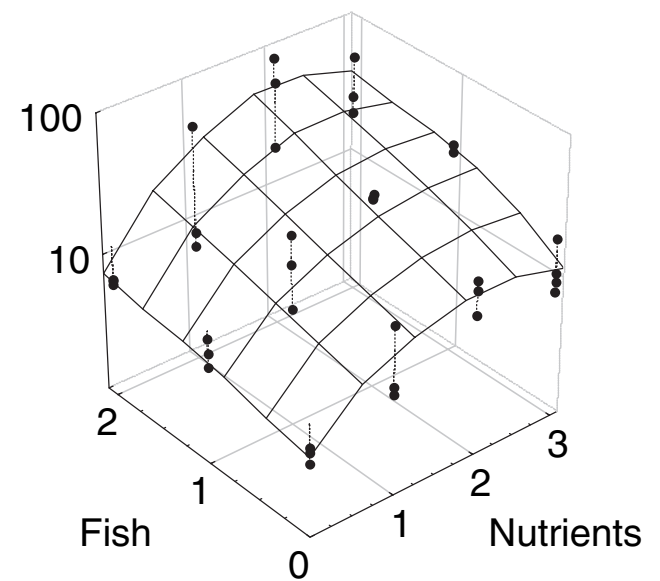

1999
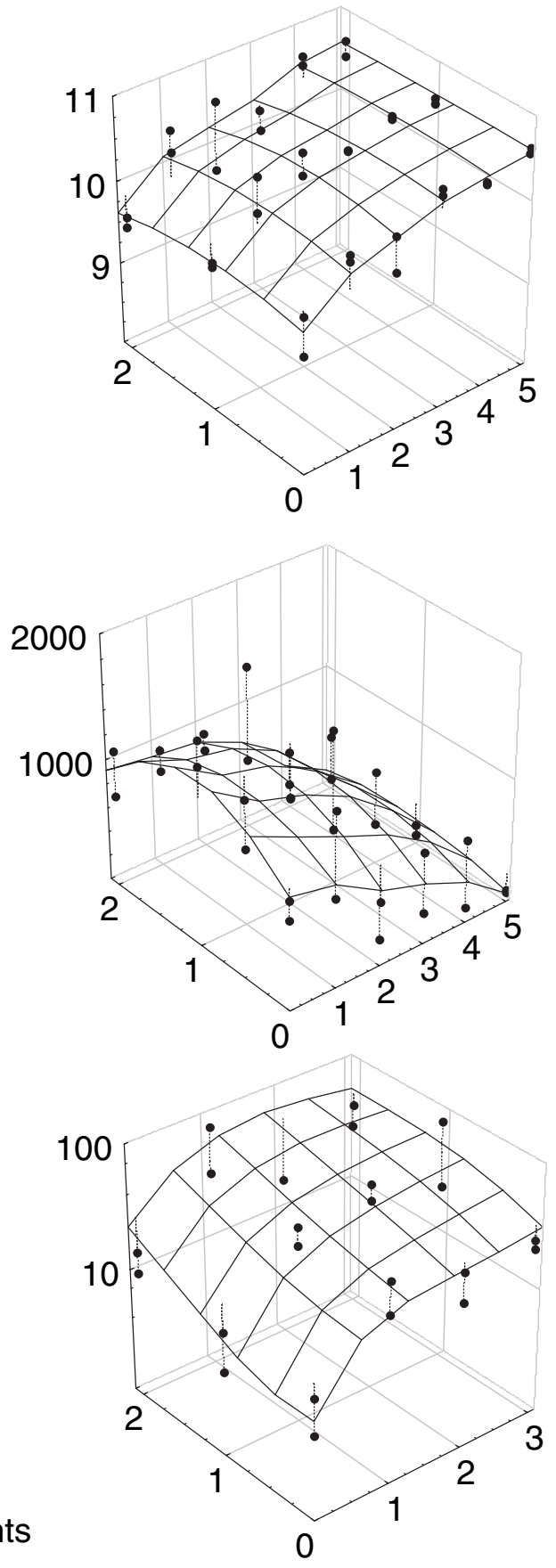

Fig. 2 Effects of nutrient and fish additions on (a) $\mathrm{pH}$, (b), Chara biomass (gram wet mass per enclosure), and (c) chlorophyll $a$ concentration $\left(\mu \mathrm{g} \mathrm{L}^{-1}\right)$ in two mesocosm experiments in Naardermeer, the Netherlands. Nutrient treatments are shown on the axis to the right, fish treatments to the left.

highest nutrient treatments. Green algal biomass significantly increased with increasing nutrient addition in both years. Only in 1998 was there also a significant increase in green algal biomass with fish density. Cryptophytes showed a similar pattern as chlorophytes in 1998, with biomass increasing with 
1998

(a) 100

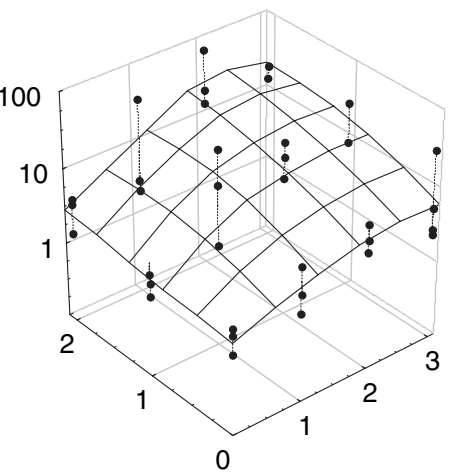

(b)

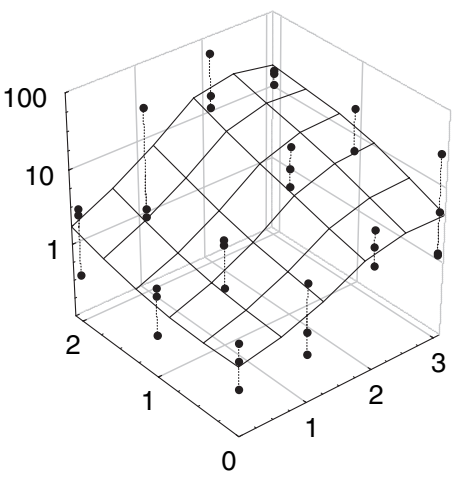

(c)

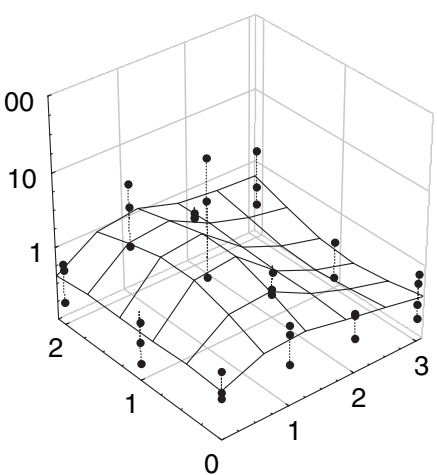

(d)

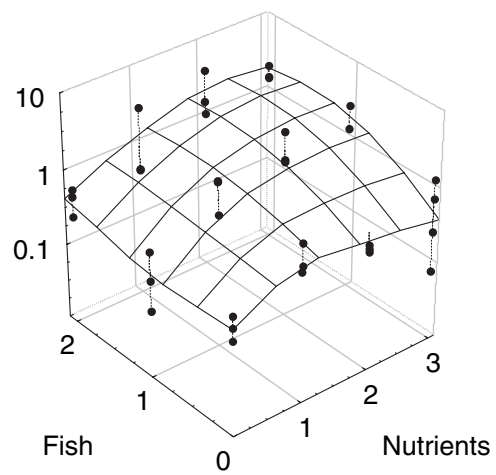

1999
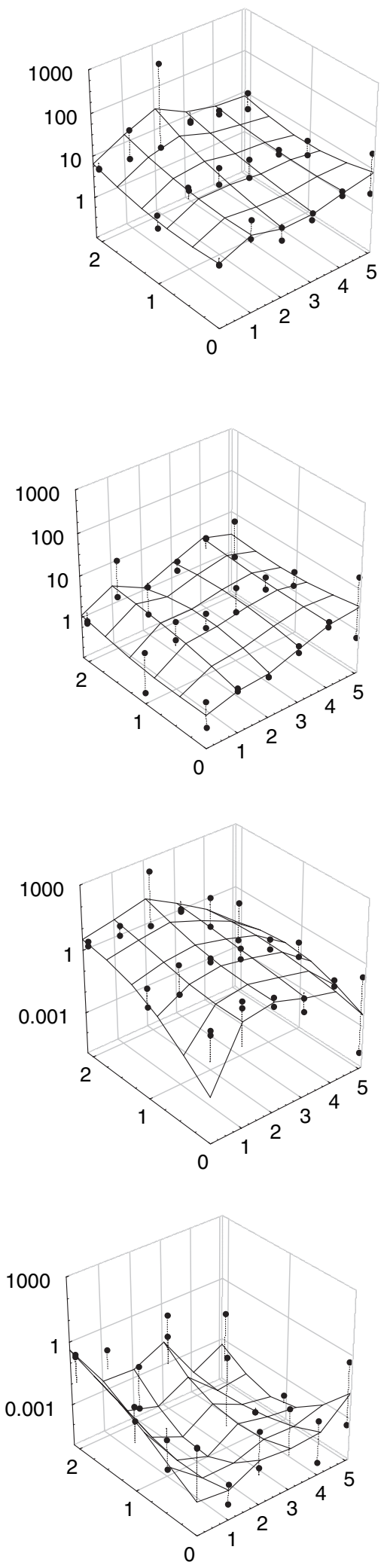

Fig. 3 Effects of nutrient and fish additions on phytoplankton biomass and composition in two mesocosm experiments in Naardermeer, the Netherlands, in 1998 and 1999: (a) total phytoplankton biomass, (b) chlorophyte biomass, (c) cyanobacterial biomass, and (d) cryptophyte biomass, all expressed as $10^{6} \mu \mathrm{m}^{3} \mathrm{~mL}^{-1}$ day $^{-1}$ ). Nutrient treatments are shown on the axis to the right, fish treatments to the left. 
1998

(a)

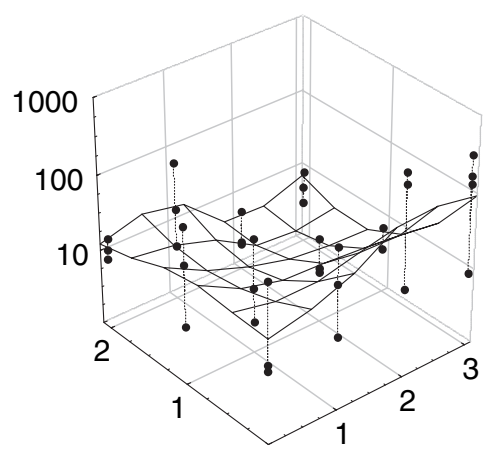

(b)

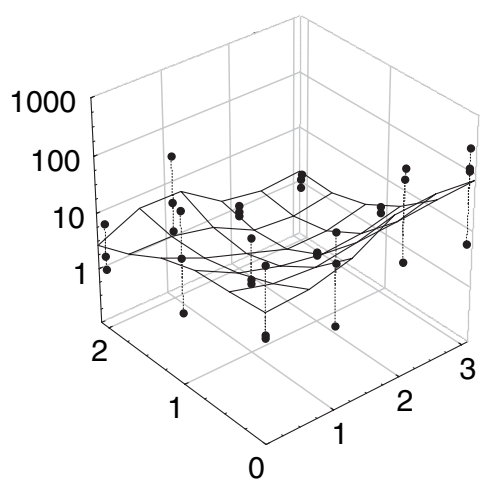

(c) 1

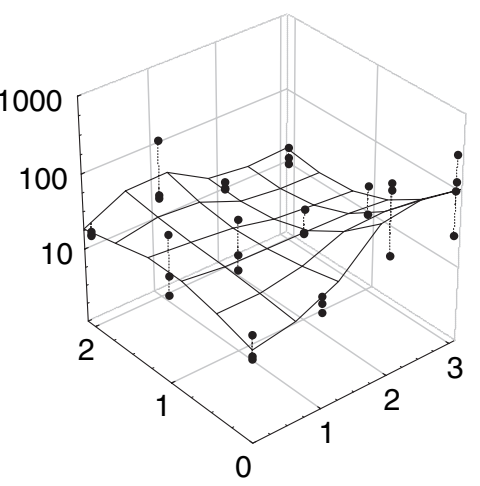

(d)

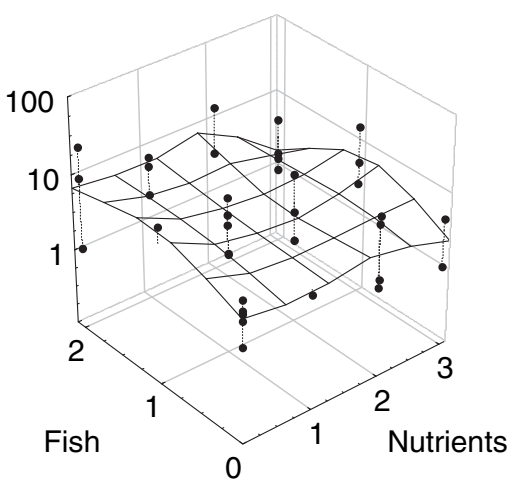

1999
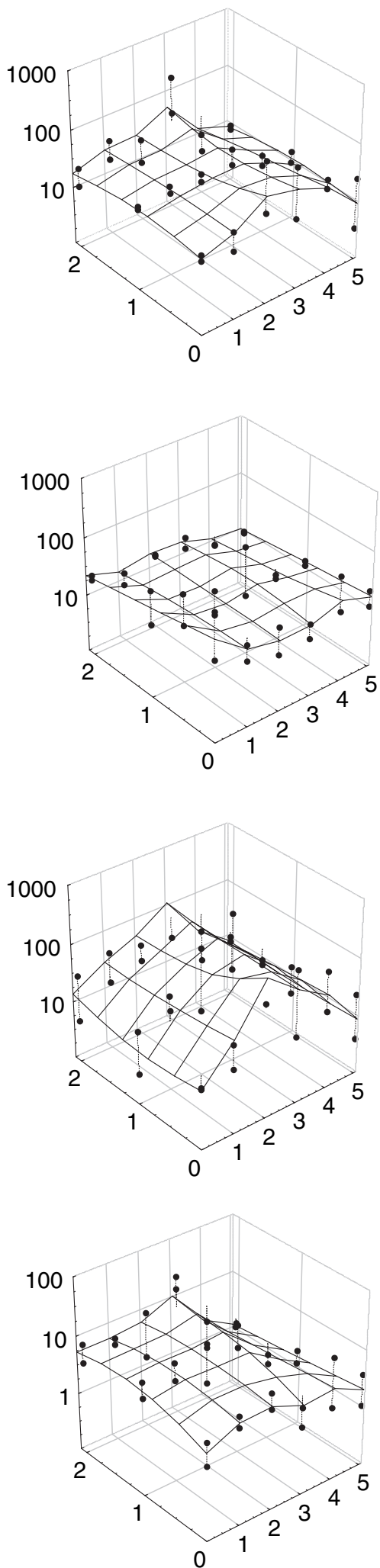

Fig. 4 Effects of nutrient and fish additions on zooplankton biomass and composition in two mesocosm experiments in Naardermeer, the Netherlands, in 1998 and 1999. (a) total zooplankton biomass, (b) large $(>500 \mu \mathrm{m})$ cladocerans, (c) small $(<500 \mu \mathrm{m})$ cladocerans, and (d) raptorial zooplankton, all expressed as $\mu \mathrm{g}$ dry mass $\mathrm{L}^{-1}$. Nutrient treatments are shown on the axis to the right, fish treatments to the left. 
both fish abundance and nutrient concentration. However, in 1999, the pattern was different; cryptophyte biomasses were much lower than in 1998 and variance much higher. Although there was a significant nutrient treatment effect, there was no clear overall response pattern.

The response of zooplankton to fish and nutrient treatments was also very different between years (Fig. 4). In 1998, but not in 1999, total zooplankton biomass significantly decreased with fish density (Table 2). Effects were similar for large cladocerans, small cladocerans and raptorial zooplankton. Nutrient treatment had no effect on zooplankton in 1998, but significantly affected total zooplankton, small cladoceran and raptorial biomass in 1999. Biomasses were highest at intermediate nutrient levels.

\section{Discussion}

The responses to fish and nutrient treatments were remarkably different between the 2 years, despite the similar set-up and location of the experiments. In both years high nutrient additions resulted in much increased water turbidity with high chlorophyll $a$ concentrations (Fig. 2c). In 1999, when the water temperature was relatively high, this resulted in a real 'switch' to a turbid state with a loss of macrophytes at the highest level of nutrient addition (Fig. 2b). In contrast, the macrophytes persisted in the 1998 experiment even at levels of nutrient addition that were up to 3.3 times higher than in 1999.

Weather conditions constituted the most important difference between the 2 years. The higher temperature in 1999 may well have contributed to the rapid loss of macrophytes in that year through indirect mechanisms involving the earlier growth of phytoplankton. In 1998, when temperature was much lower, the macrophytes survived the unfavourable effects of nutrient addition during the 5-week experiment, although deterioration of the plants was visible in the higher nutrient treatments. The response to the presence of fish also differed greatly between years. In 1998, eight of our ten standard biological variables (Stephen et al., 2004b) were affected by fish addition, whereas no significant response was observed in 1999 (Table 2).

In 1998, top-down control of phytoplankton biomass appeared to play an important role, especially in the low-nutrient treatments. This was possible because zooplankton was dominated by large cladocerans from the start (Fig. 4), with Diaphanosoma brachyurum Lieven as the most abundant species. Addition of fish greatly reduced the biomass of these large and effective grazers (Fig. 4b), resulting in an increase in phytoplankton biomass. In 1999 zooplankton was dominated by small taxa, with Ceriodaphnia pulchella Sars and Chydorus sphaericus O.F. Müller as the dominant species. Grazing on algae by large zooplankton therefore appears to have played a minor role in the 1999 experiment from the start. Even in the absence of fish the large zooplankters never reached high densities during the experiment. At the start of the experiment, densities were very low, and the 6-week experiment was probably too short for the large zooplankton to build up high densities. This is consistent with the fact that addition of rudd had no significant effects in 1999, whereas effects on zooplankton were mostly highly significant in 1998 (Table 2).

Another factor that is likely to have been important for the differences in plankton dynamics between years was the extremely high $\mathrm{pH}$ that was reached in 1999 (Fig. 3a). The highest values were measured in the third week of the experiment, ranging on average from 9.9 in the enclosures with no nutrients added to 10.6 in the enclosures with the highest nutrient addition. In the surrounding lake $\mathrm{pH}$ values were similar to the low-nutrient enclosures (Stephen et al., 2004a), so the high $\mathrm{pH}$ values were not an enclosure artefact. Daphnid population growth is markedly reduced when $\mathrm{pH}$ exceeds 10.0 (Vijverberg, Kalf \& Boersma, 1996).

Extrapolation of our results from enclosure experiments to the field situation are not straightforward, making predictions uncertain about the likelihood of a 'switch' from the Chara-dominated clear-water state to the phytoplankton-dominated turbid state. At present, nutrient loadings in Lake Naardermeer are clearly sufficiently reduced to prevent this. However, when nutrient loads are increased towards levels where the macrophyte-dominated state is being destabilised, a 'switch' is more likely to occur in warm summers, such as during our 1999 experiment.

\section{Acknowledgments}

Many thanks to Klaas Siewertsen, Jeffrey Morris, Eric Dawson, Kirsten Kessler, Slavomir Cerbin, Matthijs Begheyn, Helen Ruggiero, and Romi Burks for assist- 
ance in the field and in the laboratory, and to Mark A. Hanson and Brian Moss for valuable comments on the manuscript. This research was supported by the EUEnvironment project SWALE (Contract ENV4-CT970420).

\section{References}

Beltman B. \& Allegrini C. (1997) Restoration of lost aquatic plant communities: new habitats for Chara. Netherlands Journal of Aquatic Ecology, 30, 331-337.

Bootsma M.C., Barendregt A. \& Van Alphen J.C.A. (1999) Effectiveness of reducing external nutrient load entering a eutrophicated shallow lake ecosystem in the Naardermeer nature reserve, The Netherlands. Biological Conservation, 90, 193-201.

Crawford S.A. (1979) Farm pond restoration using Chara vulgaris vegetation. Hydrobiologia, 62, 17-31.

Jeppesen E., Søndergaard M., Kronvang B., Jensen J.P., Svendsen L.M. \& Lauridsen T.L. (1999) Lake and catchment management in Denmark. Hydrobiologica, 396, 419-432.

Meijer M-L., De Boois I., Scheffer M., Portielje R. \& Hosper H. (1999) Biomanipulation in the Netherlands: an evaluation of 18 case studies in shallow lakes. Hydrobiologia, 408/409, 13-30.

Perrow M.R., Meijer M-L., Dawidowicz P. \& Coops H. (1997) Biomanipulation in shallow lakes: state of the art. Hydrobiologia, 342/343, 355-365.

Scheffer M. (1998) Ecology of Shallow Lakes. Chapman and Hall, London.

Scheffer M., Hosper S.H., Meijer M.L., Moss B. \& Jeppesen E. (1993) Alternative equilibria in shallow lakes. Trends in Ecology and Evolution, 8, 275-279.

Scheffer M, Van den Berg M., Breukelaar A.W., Breukers C., Coops H., Doef R.W. \& Meijer M.-L. (1994)
Vegetated areas with clear water in turbid shallow lakes. Aquatic Botany, 49, 193-196.

Simons J., Ohm M., Daalder R., Boers P. \& Rip W. (1994) Restoration of Botshol (The Netherlands) by reduction of external nutrient load: recovery of a characean community, dominated by Chara connivens. Hydrobiologia, 275/276, 243-253.

Stephen D., Balayla D., Bécares E. et al. (2004a) Continental-scale patterns of nutrient and fish effects on shallow lakes: introduction to a pan-European mesocosm experiment. Freshwater Biology, 49, 1517-1524.

Stephen D., Balayla D.M., Collings S.E. \& Moss B. (2004b) Two mesocosm experiments investigating the control of summer phytoplankton growth in a small shallow lake. Freshwater Biology, 49, 1551-1564.

Van den Berg M.S. (1999) Charophyte colonization in shallow lakes: processes, ecological effects and implications for lake management. PhD Thesis, Free University of Amsterdam.

Van den Berg M.S., Coops H., Meijer M.-L., Scheffer M. \& Simons J. (1998) Clear water associated with dense Chara vegetation in the shallow and turbid Lake Veluwemeer, The Netherlands. In: The Structuring Role of Submerged Macrophytes in Lakes (Eds E. Jeppesen, Mo. Søndergaard, Ma. Søndergaard \& K. Christoffersen), pp. 339-352. Springer Verlag, New York.

Van Donk E \& Van de Bund W.J. (2003) Impact of submerged macrophytes including macrophytes on phyto- and zooplankton communities: allelopathy versus other mechanisms. Aquatic Botany, 72, 261274.

Vijverberg J., Kalf D.F. \& Boersma M. (1996) Decrease in Daphnia egg viability at elevated pH. Limnology and Oceanography, 41, 789-794.

(Manuscript accepted 27 August 2004) 